Intraoperative ultrasound versus fluorescence and X-ray cholangiography for the identification of bile duct stones, biliary anatomy and bile duct injury during laparoscopic cholecystectomy: Time for a randomised controlled trial?

Peter L Labib

Surgical Registrar

\title{
Somaiah Aroori
}

Consultant HPB \& Transplant Surgeon

Address

Department of hepatopancreaticobiliary (HPB) surgery

Derriford Hospital, Derriford road, Plymouth PL4 6PU

Corresponding author

Peter L Labib, peter.labib@nhs.net

Department of HPB surgery, Derriford Hospital, Derriford road, Plymouth PL4 6PU

Tel: +44(0)1752 202082

\section{Funding}

None

Article type

Correspondence

Submission is not based on a previous communication to a society or meeting. 


\section{Main text}

The randomised controlled trial (RCT) by Lehrskov and colleagues comparing indocyanine green (ICG) fluorescence cholangiography and X-ray cholangiography in elective laparoscopic cholecystectomy $(\mathrm{LC})$ demonstrated the non-inferiority of fluorescence cholangiography, as a non-invasive alternative for identifying the critical junction between cystic, common hepatic and common bile duct. ${ }^{1}$ Imageguided surgery can potentially reduce the risk of bile duct injury (BDI) and RCTs like this are welcome. However, ICG has several limitations in this setting including the need to be administered several minutes/hours pre-operatively for optimal imaging, limited depth penetration, poor views in the presence of blood, and the inability to identify bile duct stones. Intraoperative ultrasound (IOUS) can address many of the limitations of fluorescence and X-ray cholangiography (Table 1). IOUS can identify biliary (including the critical junction) anatomy, vascular structures, and bile duct stones. ${ }^{2} \mathrm{X}$-ray cholangiography continues to be the optimal modality for the identification of BDI once it has occurred (via identification of contrast leak/non-opacification of common hepatic/bile duct). A RCT comparing IOUS with X-ray and/or fluorescence cholangiography in LC powered to detect a difference in the rate of identifying bile duct stones as well as viewing the critical junction is warranted.

\section{References}

1 Lehrskov LL, Westen M, Larsen SS, Jensen AB, Kristensen BB, Bisgaard T. Fluorescence or X-ray cholangiography in elective laparoscopic cholecystectomy: a randomized clinical trial: Fluorescence versus $\mathrm{X}$-ray cholangiography in elective laparoscopic cholecystectomy. Br J Surg. 2020 May; 107: 655-661.

2 Dili A, Bertrand C. Laparoscopic ultrasonography as an alternative to intraoperative cholangiography during laparoscopic cholecystectomy. World J Gastroenterol. 2017 Aug 7; 23: 5438-5450. 
Table 1 Comparison of intraoperative ultrasound, fluorescence and X-ray cholangiography in the detection of bile duct stones and detection/prevention of bile duct injury in laparoscopic cholecystectomy

\begin{tabular}{|c|c|c|c|}
\hline Factor & $\begin{array}{l}\text { Intraoperative } \\
\text { ultrasound }\end{array}$ & $\begin{array}{l}\text { Fluorescence } \\
\text { cholangiography }\end{array}$ & $\begin{array}{c}\text { X-ray } \\
\text { cholangiography }\end{array}$ \\
\hline Non-invasive & $\checkmark$ & $\checkmark$ & $x$ \\
\hline No radiation & $\checkmark$ & $\checkmark$ & $x$ \\
\hline Deep tissue penetration & $\checkmark$ & $x$ & $\checkmark$ \\
\hline $\begin{array}{l}\text { Detects deep biliary } \\
\text { anatomy }\end{array}$ & $\checkmark$ & $x$ & $\checkmark$ \\
\hline Detects vascular anatomy & $\checkmark$ & $x$ & $x$ \\
\hline Detects bile duct stones & $\checkmark$ & $x$ & $\checkmark$ \\
\hline $\begin{array}{l}\text { No need for pre-operative } \\
\text { contrast administration }\end{array}$ & $\checkmark$ & $x$ & $\checkmark$ \\
\hline $\begin{array}{l}\text { Images unaffected by blood } \\
\text { in operative field }\end{array}$ & $\checkmark$ & $x$ & $\checkmark$ \\
\hline $\begin{array}{l}\text { Can be repeated intra- } \\
\text { operatively }\end{array}$ & $\checkmark$ & $x$ & $\checkmark$ \\
\hline Detects bile duct injury & Unknown & Unknown & $\checkmark$ \\
\hline Prevents bile duct injury & Unknown & Unknown & Unknown \\
\hline Learning curve & Moderate & Easy & Difficult \\
\hline
\end{tabular}

